\title{
Algerian University During the Corona Virus Pandemic: COVID-19 - Bechar University as a Sample
}

\section{Souad Guessar}

PhD, University of Tahri Mohamed- Bechar, Algeria

\section{Abstract}

In March 2020, the World Health Organization announced that the new Corona virus is a global pandemic. The World Health Organization and the public health authority of various countries are working to contain the spread of the virus through quarantine. But these crises raise the level of stress and psychological tension on individuals and society. As well as Algeria is not an exception and this research will be on the extent of the impact of the pandemic on the conduct of lessons at the universities level in Algeria, which were not equipped for such situations during the outbreak of the emerging corona virus, and try to analyze the situation and then proposing some solutions that can work if it hurts humanity and the Algerians, especially an epidemic like the Corona virus pandemic (COVID-19).

Keywords: Corona, virus, lessons, universities, Algeria

\section{Introduction}

\section{The Definition of Corona Virus Pandemic (COVID-19):}

The United Nations Development Programme defined the Corona Virus COVID-19 pandemic as a global health crisis of our time and the greatest challenge we have faced since World War Two. Since its emergence in Asia late 2019 year, the virus has spread to every continent except Antarctica.

The pandemic is much more than a health crisis; it is also an unprecedented socioeconomic crisis. Stressing every one of the countries it touches; it has the potential to create devastating social, economic and political effects that will leave deep and longstanding scars. The COVID- 19 pandemic has affected educational systems worldwide, leading to the near-total closures of schools, universities and colleges. As well as Algeria is not an exception where Algerian universities are not prepared for such situations during the outbreak of the emerging corona virus. Many universities were not fully prepared for E-learning. 


\section{E-learning}

Knowledge is not only a transfer of information from teacher to student, but also how the student receives this knowledge from a mental point of view, e-learning enables the student to take responsibility in the educational process through exploration, expression and experience, changing roles where the student becomes educated instead of a recipient and the teacher is directed instead of an expert.

Dr. Ghazi Al-Qusaybi says that this education began in Chicago and Moscow in the early 1960s, but it was not born a real birth until the Open University of Britain in 1980, initially mail and television were the main means in e-learning, but now the Internet is playing a distinct role besides the two traditional methods (Abdullah AlAziz, 2002), and Salem mentioned that elearning has gone through many stages, including the era of the traditional teacher and from it to the era of multimedia and then the emergence of the internet of information and from it to the second generation of the information network where the design of web sites became more advanced (Abdullah Al-Aziz, 2002).

\section{E-Learning Goals}

Some of the goals to be achieved from e-learning include:

- -Providing a rich and multi-source educational environment that serves the educational process in all its aspects.

- Reformulating roles in the way the process of education and learning is carried out in accordance with the developments of educational thought.

- Creating incentives and encouraging communication between the scientific educational system such as communication between teachers and students, university and the surrounding environment.

- Modelling and presenting education in a standard form.

- The transmission of educational experiences through the creation of channels of communication and forums that enable teachers and all those interested in the educational affairs to exchange opinions and discussion through a specific site that brings them together in a virtual room despite the distance.

- Preparing a generation of teachers and learners capable of dealing with the technology and skills of the times and developments in the world.

- Help to spread technology in the society to become an electronic intellectual and keep up with what is going on in the far reaches of the earth.

- Providing education that suits different age groups, taking into account the individual differences between them (Abdullah Al-Aziz, 2002).

- Providing the largest number of people in the community to access education 
and training, by overcoming the obstacles of space and time, also reduce the cost of education in the long term, in addition, the provision of e-learning does not require huge budgets to create large buildings and classrooms, and the spread of e-learning also due to the flexibility of learning, and the technical development and intense competition between the providers of study and training programs made these programs accessible to large segments of society, which led in turn to the spread of e-learning.

- E-learning is considered the optimal exploitation of human and material resources; it solves the problem of rare disciplines. (Al-Mabrik, 2002)

- Transform the traditional educational philosophy based on the group to the individual by time, curriculum and exercises depend on the level and skills of the student and not on the average of the group.A distinguished student can apply not dependent on the weak.

- The lowest level student has time to raise his level.

\section{E-learning techniques}

E-learning is based on the use of different electronic means in the education process, whether real formal education that takes place within the classroom or distance learning, and these electronic means are: computer, internet, television, radio, video, video conferencing.

1- Computer: It is used as an educational tool to help the teacher and the learner, and has several types or software methods to use the computer in formal or electronic education:

- Training and practice software,

- Special education software,

- Simulation software,

- Dialogue software,

- Problem solving software,

- Survey software,

- Multimedia software,

- Speech processing software,

- Supermedia software,

2- Internet: where all its subscribers are provided services in all fields of life in general and in the educational process and e-learning in particular, including:

- -E-mail service, 
- Information transfer protocol,

- Web service,

- Communication service to another computer,

- Speech service,

- Dialogue service,

- Mailing lists service,

- Finger service for investigation,

- System search service,

- Internet phone call service,

- Internet broadcasting service,

- White page indexing service,

- Automated copying service (Al-Mabrik, 2002),

3- E-book: is a new method of displaying information with its images, movement, audio conferences and film clips in the form of an integrated book that is copied by the bug of cDs, and is browsed through the computer and can be searched for or subject easily ( Ahmed Mohamed, 2004).

4- Visual Book: A book that contains hundreds of pages and provides the reader with information in a visual, audio and readable image, easy to modify and develop by the user, can be read or seen by how many people at the same time from all over the world (Ahmed Mohamed, 2004).

5- Video Conference: A visual audio communication between several people who are located in geographical lye spaces where ideas, experiences and information elements are discussed and exchanged in an interactive atmosphere aimed at achieving cooperation and mutual understanding (Ahmed Mohamed, 2004).

6- Satellite programs: This technology is characterized by the speed of transmission of programs and events to all parts of the earth in addition to the possibility of transferring written and spoken messages, and to be used in e-learning (Abdullah Yahya, 2006).

7- Text and graphic images remotely: This technique is used to send symbolic digital information as part of the TV signal to be displayed to the future and be in the form of text or diagram after decoding (Abdullah Yahya, 2006).

8- Audio conferences: This technique consists of the use of a regular phone connected to several telephone lines that connect the lecturers remotely to a number of students in different places and away from the classroom and characterized by interaction 
between them (Abdullah Yahya, 2006).

9- Interactive video: is the integration of computer and video and the integration process included the same video that played an active role where studies indicated that the interaction between the learner and the educational program improves the performance of the learner and helps to keep the information for a longer time (Zakaria, 2005).

10- Virtual campus: a website that the student can access and walk between virtual colleges and departments and contact boards by connecting to the Internet without actually going to the institution study site (Zakaria, 2005).

11- Virtual classroom: A set of activities that resemble the activities of the traditional classroom carried out by a teacher and a student, separated by spatial barriers but they work together at the same time regardless of where they are where they are where students interact with each other through online dialogue, and they print messages that everyone who contacted the network can see (Zakaria, 2005).

\section{The Role of the Teacher in E-Learning}

The role that focuses on the teacher in education in general is an important and key role in the educational process because it is one of its pillars, and in e-learning the role of the teacher increases and this is contrary to what some believe that e-learning leads to the marginalization of his role and ultimately dispensed with it, and in order to become an e-teacher needs an intellectual formulation through which he is convinced that the traditional teaching method must change to suit the vast amount of knowledge that is encased in all areas of life, It is necessary to learn modern methods of teaching and effective strategies and to deepen understanding of its philosophy and master its application, so that it can convey this thought to its students and practice it through e-learning techniques (Abdel-Wakeel,2002).

\section{E-University Education}

The educational process needs to interact between the teacher and the learner and the students among themselves, and the need to catch up with the university eeducation does not mean the dispensation of the traditional university or teacher, but we are in an era of increasing demand for education where it is not possible to settle for cement and iron universities, and it is necessary to move in part to air universities or open or electronic universities, the names are multiple and one concept, the need for these universities increases year after year. Because almost every year thousands of students coming to universities do not have seats to study, and the options in front of them are limited and narrow, this is the case of opening the horizon of choice by introducing e-university education.( Abdel- Wakeel,2002).

\section{Virtual University Concept}

A university institution that provides telecommunications education through modern electronic media, the product of information technology and communications such as 
the Internet, channels and satellites that publish lectures, programs, courses, design and production of educational information, evaluate students and implement successful goals for specific purposes (Abdel-Wakeel,2002).

It is also an academic institution that aims to ensure the highest levels of higher education for students in places of residence through the Internet, through the creation of an integrated elearning environment based on a sophisticated network ( Abdel-Wakeel,2002).

\section{The difficulties of applying e-learning are}

On the learners' hand:

- Difficulty in switching from the traditional method of education to the modern way.

- Difficulty of application in some materials.

- The difficulty of the availability of computers in some students.

- Directing some teachers may lead to misperception.

- On the teachers' side:

- Difficulty dealing with learners who are not trained in self-education.

- Difficulty to make sure that the student is able to use the computer.

- The degree of complexity of some materials.

- Copyright problem (Al-Sartawi, 2004).

It was added that there are a number of obstacles to achieving e-learning, the most prominent of which are:

- Poor infrastructure for most developing countries.

- The difficulty of internet access and its high fees.

- Lack of knowledge of computer-learning internet browsing techniques.

- Difficulty in applying the tools and means of evaluation.

- The failure of some official bodies to recognize the certificates granted by electronic universities.

- Faculty is not convinced of the use of electronic media.

- High cost in the design and production of educational software ( Ihab Mukhtar, 2005). 


\section{International Experiences in E-Learning}

Many countries have conducted pioneering experiments in the application of different elearning systems, and here we will review some of them:

Japan experience:

Japan started in 1994 with a television network project in which educational materials are broadcast via video materials for schools on demand through cable as a first step to distance education, and in 1995 started the 100 schools project, where schools are equipped for the purpose of processing and developing educational activities and educational software through that network.

In 1996-1997, the Center for Electronic Libraries approved the support of scientific research, support, especially in terms of scientific research techniques and support for the employment of Internet networks in institutes and colleges, and Japan is now one of the countries that officially apply modern e-learning methods in most Japanese schools.

\section{Experience USA:}

In 1995, the United States completed all of its plans for computer applications and was interested in training teachers to help their colleagues, also students, and providing the infrastructure for the process (21).

In the United States of America today, more than 2,000 higher education institutions broadcast at least one of their programs online, and this percentage increases annually and these universities vary in the number of online courses and specialties offered by them (Polfelaf, 2013).

Malaysia experience:

In 1996, the State Comprehensive Development Committee developed a comprehensive technical plan and a symbol of education in it in the 1996 education contract, which aims to introduce computers and internet connection in each classroom, and in 1999 the percentage of schools reached more than 90 percent and called smart schools.

Experience Britain:

In Britain, a national education network has been established, through which more than 32,000 schools have been connected to the Internet, nine million students, 40,000 teachers, and each student has been given an electronic address and various educational sites have been connected to this network, and this process is constantly evolving in Britain.

\section{E-Learning in Algeria - Bechar University Model}

Education in Algeria is a priority in development projects, and in its future policy, as well as the subject of attention attached to the state in its various segments and 
categories, believing that education is the best investment and that the educated individual is the basis of progress and advancement in a changing society, developed and open to all that is new.

Most universities in the developed world are turning to the increasing use of elearning due to the extreme importance that distinguishes it from traditional education, coinciding with the emergence and development of the informationcommunication revolution and the accompanying unprecedented flow of information and knowledge, the form of e-learning is one aspect, because of the uniqueness of this unconventional pattern of easy use of its services, and the provision of educational opportunities for people who may be It is difficult for them to join the education system in its traditional form, in addition to contributing to overcoming some of the problems of higher education.

Despite the delay of our universities in this field, they are currently witnessing some attempts in this context, which shows that the use of e-learning in higher education levels in particular, is an end and goal sought by all educational institutions advanced in Algerian universities, where work has begun on the preparation of infrastructure, the preparation of human resources, as the state has provided Algerian universities with internet lines, computerization centers and information in all college locations, Despite all this, communication is still weak between faculty members and students, and the lack of online content of courses all the time and in a way that encourages study, many faculty members still rely on traditional teaching to provide lectures and lessons as a way of teaching, and this calls for knowing the reality of using this type of education in Algerian universities. (Polfelaf, 2013)

\section{The reality of e-learning at the University of Bechar}

Among the most important concepts related to e-learning are the concept of distance learning, direct learning, open learning, online learning using simultaneous or recorded lessons, video technologies (image and sound), electronic presentation techniques (video lectures broadcast over the Internet).

Through the results of some researches and studies in this context it turns out that professors are sufficiently familiar with the concept of e-learning and have a good knowledge of the most important concepts related to what allows to say that theoretical knowledge of this modern technology is not a problem for professors and this is because they are either familiar with what is published about them in scientific journals and books or because they are users of these techniques in teaching as well as in research work.

The application of e-learning at the university varies from department to college to college, increasing its use in scientific and technical disciplines, while reducing its use in scientific and applied disciplines more than theoretical scientific disciplines. 
Its use is generally average, as presentation techniques such as "Data Chow", i.e. the presentation of information, and the preparation of lectures in the form of PowerPoint, have evolved remarkably, but the availability of lessons and availability on the Internet is still somewhat decent, as some professors resort to showing their lessons in their own blogs instead of the university site because of its weakness and lack of greetings.

With regard to the difficulties faced by the application of e-learning at the Algerian University, they can be summarized in the following points:

- Poor internet, where there must be a high flow speed, which is what Algeria lacks, as the speed of flow according to the latest statistics is among the weakest in the world.

- The weakness of university sites, their non-permanent and non-organization, due to the lack of specialists in this field.

- The lack of awareness of the professor as well as his lack of interest in this type of education due to the lack of interest on the part of officials in this type of education because they are from the traditional education generation.

- The university's lack of interest in this type of education, and its lack of activation by states by not harnessing all the possibilities for this type of education.

- The student's lack of desire for this type of learning because he wants readymade lectures, and prefers the traditional method so that the latter is characterized by the lack of effort on the part of the student who is content to receive only. (Polfelaf, 2013)

\section{Conclusion}

The aim of this research is to study the topic of e-learning in light of the current transformations and future stakes and what challenges face its application at the University of Algeria in particular. The impact of the pandemic on the conduct of lessons at the universities level in Algeria, which were not equipped for such situations during the outbreak of the emerging corona virus, and try to analyze the situation and then proposing some solutions that can work if it hurts humanity and the Algerians, especially an epidemic like the Corona virus pandemic (COVID-19). With our work and hard work with cooperation and perseverance we can reach, achieve our goals no matter how difficult we face, we must try and the country has given us a lot and it is time to change, to succeed, to develop.

\section{References}

[1] Adel Al-Sartawi and happiness, using the computer and the Internet in the fields of education, 1st edition, Dar Al-Shorouk for Publishing and Distribution, Jordan, 2004. 
[2] Al-Ibrahim Ibrahim Abdel-Wakeel, Using Computer in Education, 1st edition, Dar Al- Fikr, Amman, 2002.

[3] Al Muhi Abdullah Yahya, Quality in E-Learning from Design to Education Strategies, working paper submitted to the International Conference on Distance Education 2729 March 2006, Muscat, Oman.

[4] Al-Musa Abdullah Al-Aziz, e-learning, its concept, characteristics, benefits, and obstacles. A working paper submitted (for a symposium on the future school), College of Education, King Saud University, 23-24 October 2002.

[5] Grove. Anoly. E-learning retrived 22 march 2004 internet web site http: /www.cognitivedesignsolutions.com.e-learning.

[6] Haifa Al-Mabrik, Method of lecture in university education using e-learning with a proposed model and a working paper for the Symposium of the Future School, College of Education, King Saud University, 23-24 October 2002.

[7] Ibrahim Polfelaf, Adel Sheheb, the reality of e-learning at the Algerian University - a field study - Introduction to the third international conference on: "E-learning and distance education", 2013, Riyadh, Saudi Arabia.

[8] Lal Zakaria and Al-Jundi Alia, Electronic Communication and Educational Technology, 4th edition, Obeikan Library, Riyadh, 2005.

[9] Muhammad Ihab Mukhtar, Distance Learning and its Challenges for ELearning, Working Paper Presented to the 12th Scientific Conference on Information Systems and Technology, Cairo, 15-17 February 2005.

[10] Salem Ahmed Mohamed, Educational Technology and Technology Education, Cairo 2004. 